Profit: Jurnal Kajian Ekonomi dan Perbankan 3 (1) 2019. P: 14-29

PROFIT : JURNAL KAJIAN EKONOMI DAN PERBANKAN

https://ejournal.unuja.ac.id/index.php/profit

E-ISSN : 2597-9434

\title{
NILAI FILOSOFI HALAL DALAM EKONOMI SYARIAH
}

Murtadho Ridwan*

- STAIN Kudus

Email;

murtadhoridwan@gmail.com

\section{Abstract:}

Secara konseptual penelitian ini menggambarkan nilainilai filosofis halal pada suatu produk perspektif ekonomi syariah. Mengkaji tentang halal tidak dapat dipisahkan dari haram karena keduanya saling berkaitan. Filsafat halal dalam Islam merupakan kajian yang belum terungkap sehingga untuk memahami filsafat halal diperlukan kajian mendalam dari semua aspek. Halal dan haram merupakan aturan Allah SWT, jika seseorang mentaati aturan itu, maka ia telah beribadah kepada Allah SWT. Aturan halal dan haram ditetapkan untuk menjaga kehormatan manusia dan mewujudkan kehidupan yang layak dan baik bagi mereka. Tulisan ini untuk mengungkap filsafat halal dalam ekonomi Syariah. Untuk mencapai tujuan itu, penulis mencoba mendiskripkan aturan halal dalam normative Alquran, halal dalam hukum Islam, dan halal dalam ekonomi Syariah.

Dalam hukum Islam terdapat beberapa prinsip dasar yang perlu difahami dalam hukum halal dan haram, diantaranya : yang dapat menentukan halal dan haram hanyalah Allah SWT. Kemudian "Asal segala sesuatu (yang diciptakan Allah SWT) adalah halal atau mubah (boleh),". Yang ketiga, Sesungguhnya Allah hanya menghalalkan sesuatu yang baik dan mengharamkan sesuatu yang buruk (kotor), dan lain sebagainya.

Hasil dari penelitian ini diperoleh bahwa jika manusia mematuhi ajaran agama terkait halal dan haram dalam menjalankan kehidupan ekonominya dengan baik dan terarah, baik dari segi produksi, konsumsi, maupun aktifitas pertukaran, maka kehidupan manusia akan terarah sesuai dengan ajaran dan pedoman dalam syariat islam

Keywords: Filosofi, Halal, Ekonomi Islam 


\section{Pendahuluan}

Mengkaji tentang halal tidak dapat dipisahkan dari haram karena keduanya saling berkaitan. Tema halal dan haram merupakan tema yang sangat penting dalam Islam karena halal dan haram sangat berkaitan dengan ajaran agama Islam secara menyeluruh, baik dalam hal akidah, ibadah, akhlak, muamalah dan yang lain.

Allah SWT menciptakan manusia dan jin untuk beribadah dan mengabdi kepada-Nya. Allah SWT menegaskan hal itu dalam firman-Nya: "Dan Aku tidak menciptakan jin dan manusia melainkan supaya mereka beribadah kepada-Ku." (QS. Adzdzariyat (51): 56). Dalam beribadah ada banyak aturan yang telah ditetapkan Allah dan harus ditaati dan diikuti oleh manusia.Diantara aturan yang ditetapkan Allah SWT adalah aturan tentang halal dan haram.

Halal dan haram merupakan aturan Allah SWT, jika seseorang mentaati aturan itu, maka ia telah beribadah kepada Allah SWT. Aturan halal dan haram ditetapkan untuk menjaga kehormatan manusia dan mewujudkan kehidupan yang layak dan baik bagi mereka. Barang siapa mentaatidan menjalankan aturan halal dan haram, maka ia berhak mendapatkan kebahagiaan dan kesejahteraan karena ia telah beriman dan berada di jalan yang benar. Dan barang siapa yang menolak aturan halal dan haram, maka ia telah membangkang perintah Allah SWT dan telah melampaui batas yang telah ditentukan Allah SW'T.

Aturan halal dan haram tidak hanya berkaitan dengan perilaku dan aktifitas manusia. Aturan halal dan haram berkaitan juga dengan kekayaan yang diperlukan manusia untuk memenuhi kebutuhan hidup.Kekayaan memiliki kedudukan tinggi dalam Islam karena kekayaan adalah kualitas kedua dibawah agama, kekayaan tidak dijauhi melainkan diikat dengan nilai agama. ${ }^{1}$ Untuk mendapatkan kekayaan, Islam mewajibkan manusia untuk bekerja. Bekerja diwajibkan Islam untuk memperoleh anugrah Allah dan rezkidengan cara yang benar.

Sebagai seorang Muslim segala usaha yang dilakukan hendaknya sesuai dengan apa yang telah digariskan Allah, yang tertuang dalam aturan Islam. Dengan mengikuti petunjuk-petunjuk tersebut, hasil usaha yang diperoleh merupakan hasil yang halal, bersih dan diridhai. Sekarang ini banyak cara yang dilakukan manusia dalam memperoleh rezki, baik dengan cara yang diridhai Allah maupun yang menyimpang. Banyak orang yang sudah tidak peduli lagi mana haram mana halal dalam mencari rezki. Sehingga rezki yang didapat untuk memenuhi kebutuhan hidup tidak diketahui statusnya.

${ }^{1}$ M. Antor Athoillah and Bambang Q-Anees, Filsafat Ekonomi Islam (Bekasi: Penerbir Sahifa, 2013).p. 69.

15 Profit : Jurnal Kajian Ekonomi dan Perbankan 
Allah SW'T telah menegaskan: "Hai sekalian manusia, makanlah yang halal lagi baik dari apa yang terdapat di bumi, dan janganlah kamu mengikuti langkah-langkah setan, karena sesunggubnya setan itu adalah musuh yang nyata bagimu." (QS. Albaqarah (2): 168). Ayat ini memberi pengertian pada kita bahwa kita harus memakan makanan yang halal dan baik. Halal berarti barang tersebut halal zatnya sesuai dengan yang telah ditetapkan Allah. Sedangkan baik (tayyib) berarti barang tersebut didapatkan dengan carayang baik.

Filsafat halal dalam Islam merupakan kajian yang belum terungkap sehingga untuk memahami filsafat halal diperlukan kajian mendalam dari semua aspek. Tulisan ini bertujuan untuk mengungkap filsafat halal dalam ekonomi Syariah. Untuk mencapai tujuan itu, penulis mencoba mendiskripkan aturan halal dalam normative Alquran, halal dalam hukum Islam, dan halal dalam ekonomi Syariah.

\section{Pembahasan}

\section{Halal dalam Al-Qur'an}

Halal sudah menjadi istilah yang popular dalam ajaran Islam. Halal biasanya digunakan untuk menyebut makanan dan minuman yang boleh dikonsumsi menurut Islam. Namun sebenarnya, istilah "halal" tidak hanya digunakan untuk menyebut makanan dan minuman yang boleh dikonsumsi. Dalam konteks yang lebih luas, istilah "halal" merujuk pada segala sesuatu yang diizinkan atau dibolehkan menurut ajaran Islam yang mencakup aktivitas, tingkah laku, cara berpakaian, cara mendapatkan rezeki dan sebagainya.

Kata "Halal" berasal dari bahasa Arab dari akar kata "Halla - Yabullu - Hallan wa Halalan yang berarti bertahalul (keluar dari ihram), dibolehkan atau diizinkan. Jika kata tersebut dikaitkan dengan suatu barang maka berarti halal (dimakan atau diminum). Namun jika dikaitkan dengan tempat maka kata tersebut berarti berhenti, singgah, tinggal atau berdiam. ${ }^{2}$ Kata "halal" merupakan bahasa Arab yang sangat masyhur dan telah diserap menjadi bahasa Indonesia.

Dalam Alquran, kata "halal"dan derivasinya disebut sebanyak 48 kali dan terdapat pada 20 Surah serta memiliki arti atau makna yang berbeda-beda. ${ }^{3}$ Perbedaan arti atau makna kata "halal" dalam Alquran dapat dikelompokkan menjadi dua; Pertama, yang memiliki makna atau arti berkaitan dengan makanan dan minuman seperti QS. Albaqarah (2): 168, QS. Almaidah (5): 88, QS. Alanfal

${ }^{2}$ Ahmad Warson Munawwir, Al-Munawwir (Kamus Arab-Indonesia) (Surabaya: Pustaka Progresif, 1997). p. 291

${ }^{3}$ Muhammad Hasan Hamshi, Quran Karim, Tafsir Wa Bayan (Beirut: Dar al-Rasyid, n.d.). p. 67. 
(8): 69 dan QS. Alnahl (16) 114. Kedua, yang memiliki makna atau arti yang berkaitan dengan aktivitas, perilaku, atau tindakan seperti QS. Albaqarah (2): 187, QS. Albaqarah (2): 275, dan QS. Annisaa (4): 19.

Diantara contoh kata "halal" dalam Alquran yang berarti makanan atau minuman adalah firman Allah SWT yang artinya: "Hai sekalian manusia, makanlah yang halal lagi baik dari apa yang terdapat di bumi, dan janganlah kamu mengikuti langkah-langkah syaitan karena sesunggubnya syaitan itu adalah musuh yang nyata bagimu.” (QS.Albaqarah (2): 168). Sedangkan contoh yang berarti aktivitas adalah firman Allah yang artinya: “... padahal Allah telah menghalalkan jual beli dan mengharamkan riba.” (QS.Albaqarah (2): 275)

Ayat 168 surah Albaqarah tidak hanya ditujukan kepada orang-orang yang beriman saja, tetapi ditujukan untuk seluruh manusia. Ini menunjukkan bahwa bumi disiapkan Allah untuk seluruh manusia, baik yang beriman maupun yang tidak beriman. Semua manusia diperintah untuk mengkonsumsi makan yang halal yang ada di bumi. ${ }^{4}$ Segala makanan dan minuman yang akan dikonsumsi sudahmendapatstandar kelayakan dari Allah SWT,yaitu halal dan tayyib (baik).Segala hal yang akan dikonsumsi orang yang beriman baik berupa makanan, minuman, pakaian, kendaraan haruslah berstandar halal dan tayyib (baik).

Allah SWT telah menentukan standar halal dan tayyib (baik) untuk dikonsumsi manusia, khususnya orang yang beriman. Hal ini karena tidak semua yang diciptakan Allah otomatis halal dimakan atau digunakan manusia. Allah menciptakan tikus, ular, binatang buas bukan untuk dimakan tetapi untuk penyeimbang ekosistem alam. Dengan demikian, tidak semua yang ada di bumi menjadi makanan yang halal karena bukan semua yang diciptakanuntuk dimakan manusia, meskipun semua untuk kepentingan manusia. Oleh sebab itu Allah SWT memerintakan untuk makan yang halal. ${ }^{5}$

Selain halal, Allah SWT juga menentukan standar tayyib (baik) bagi makanan yang dikonsumsi sebagaimana terdapat pada ayat 168 surah Albaqarah. Tayyib (baik) artinya makanan yang dihalalkan Allah adalah makanan yang berguna bagi tubuh, tidak merusak, tidak menjijikkan, enak, tidak kadaluarsa dan tidak bertentangan dengan perintah Allah. Tayyibberasal dari kata bahasa Arab yang berarti suci, baik, bagus, lezat, halal, subur, memperkenangkan, dan membiarkan. ${ }^{6}$ Dan Quraish

${ }^{4}$ M. Quraish Shihab, Tafsir Al-Misbah, Kesan, Pesan Dan Keserasian Al-Quran (Jakarta: Lentera Hati, 2001). Vol. 1, p. 456.

${ }^{5}$ Ibid.

6Munawwir, Al-Munawwir (Kamus Arab-Indonesia). p. 874. 
Shihab berkata bahwa tayyib berarti pokok segala sesuatu yang disenangi oleh panca indra dan jiwa manusia. ${ }^{7}$

Menurut al-Shabuni, tayyibadalah makanan yang menurut tabiatnya dianggap baik dan bermanfaat untuk diri orang yang mengkonsumsi dan tidak membahayakan badan dan akal orang tersebut. ${ }^{8}$ Makanan yang demikian akan dirasa nikmat oleh yang mengkonsumsi, mudah dicerna, dan merupakan makanan yang baik, tidak dianggap kotor serta menjijikkan, dan umumnya tidak membuat perut sakit atau bahaya lain. Artinya, syarat makanan yang bisa dikonsumsi tidak hanya halal tetapi juga harus tayyib (baik). Bisa jadi ada makanan halal tapi tidak baik untuk seseorang seperti gula untuk penderita diabet.

Sedangkan ayat 275 surah Albaqarah menjelaskan bahwa sesungguhnya Allah telah menghalalkan jual beli dan mengharamkan riba. Hal itu sangat bertentangan dengan anggapan orangorang yang bermuamalah dengan riba, mereka menyamakan antara jual beli dengan riba. Mereka beranggapan bahwa riba sama persis dengan jual beli sehingga riba hukumnya halal. Namun anggapan itu ditolak oleh Allah dalam ayat tersebut dengan menyatakan; "padahal Allah telah menghalalkan jual beli dan mengharamkan riba." Jual beli dihalalkan oleh Allah SW'T karena di dalam jual beli terdapat pertukaran manfaat yang dibutuhkan masyarakat, sedangkan riba diharamkan karena di dalam riba terdapat bahaya yang dampaknegatifnya ada pada individu dan masyarakat. ${ }^{9}$

Dalam ayat 275 surah Albaqarah kata halal diungkapkan dengan mengunakan kalimah Fi’il(kata kerja) sehingga menunjukkan aktifitas yang dihalalkan. Artinya ayat 275 menjelaskan tentang aktifitas jual beli yang berbeda dengan praktik riba. Karena jual beli dihalalkan sedangkan riba diharamkan. Hal ini berbeda dengan ungkapkan pada ayat 168 surah Albaqarah yang menjelaskan tentang makanan. Di dalam ayat 168, halal diungkapkan dengan bentuk Masdar sehingga iamenjadi sifat barang yang dimakan.

${ }^{7}$ M. Quraish Shihab, Ensiklopedi Al-Quran: Kajian Kosakata (Jakarta: Lentera Hati, 2000). p. 1005. ${ }^{8}$ Muhammad Ali Shabuni, Shafwah Al-Tafasir (Kairo: Dar al-Salam, 1996). Vol. 1, p. 99. 9Ibid. p. 158. 


\section{Halal dalam Hukum Islam}

Dalam syariat Islam, istilah halal merupakan lawan dari istilah haram. Haram didefinisikan dengan segala sesuatu yang dituntut syara' untuk ditinggalkan. ${ }^{10}$ Artinya, sesuatu yang jika dikerjakan akanterkena seksa dan jika ditinggalkan akan mendapat pahala.Sedangkan halal diartikan dengan segala sesuatu yang boleh dikerjakan dan boleh ditinggalkan dengan tanpa konsekwensi pahala dan seksa. Dalam hukum Islam, halal biasa disebut dengan istilah Mubab. ${ }^{11}$

Halal dan haram merupakan istilah umum yang sudah diketahui masyarakat. Bagi masyarakat awam, opini mereka tentang pengertian halal merujuk kepada hal-hal yang dibenarkan atau dibolehkan oleh syariah, sedangkan haram adalah hal-hal yang dilarang atau dicegah oleh syariah.2 Perkara-perkara yang telah jelas dan mudah diketahui melalui teks nash tentang status halal atau haramnya wajib diterima umat Islam tanpa persoalan lagi. ${ }^{12}$ Tetapi, ada beberapa hal yang tidak disebut secara jelas dalam Alquran ataupun Sunnahyang dikenal dengan istilah syubhat, maka penentu hukum halal atau haramnya menyebabkan persoalan.

Telah diriwayatkan dari Abu Abdullah al-Nu'man bin Basyir, Nabi SAW bersabda: "Sesungghubnya halal itu jelas, dan haram itu juga jelas. Diantara keduanya ada hal-bal yang tidak jelas (syubhat) yang tidak diketahui oleh banyak orang. Barang siapa takut atau menjaubui hal-hal yang syubhat, maka ia telah mencari kebersiban agama dan harga dirinya. Dan barang siapa terjerumus pada hal-hal yang tidak jelas (syubhat), maka ia telab terjerumus kedalam perkara haram."(HR. al-Bukhari dan Muslim)

Berdasarkan hadis di atas, al-Qardhawi berpendapat bahwa ada kaidah yang terkenal yang berkaitan dengan prinsip dasar halal dalam Islam, yaitu: "Asal segala sesuatu (yang diciptakan Allah SWT) adalab halal atau mubah (boleb)". Tidak ada sesuatu apapun yang diharam kecuali berdasarkan teks nash yang berasal dari Alquran ataupun Sunnah yang dengan jelas mengharamkannya. Seandainya tidak ada teks nash yang jelas menunjukkan keharamannya, maka sesuatu itu tetap pada hukum asalnya, yaitu boleh. ${ }^{13}$

Kaidah ini berlaku pada segala perilaku yang tidak berkaitan langsung dengan agama seperti perilaku yang didasarkan pada adat kebiasaan dan kegiatan muamalah.Perlu dipisahkan hukum halaldan haram pada kehidupan pribadi, kehidupan keluarga, dan kehidupan masyarakat. Perlu juga

${ }^{10}$ Wahbah Zuhaily, Ushul Figh Al-Islami (Beirut: Dar al-Fikr, 1996). p. 80.

${ }^{11}$ Ibid. p. 87.

${ }^{12}$ Abdul Mukti Thabrani, “Esensi Ta'abbud Dalam Konsumsi Pangan,” al-Ihkam 8, no. 1 (2013): 55-68.

${ }^{13} Y$ usuf Qardhawi, Al-Halal Wa Al-Haram Fi Al-Islam (Kairo: Maktabah Wahbah, 2000). p. 21.

19 Profit : Jurnal Kajian Ekonomi dan Perbankan 
dibedakan halal dan haram dalam bidang makanan dan minuman serta tempat tinggal. Perkara yang diharamkan sangat terbatas dan bisa dihitung, sedangkan yang dihalalkan sangatlah banyak. Semua makanan hukumnya halal kecuali empat hal yang disebutkan Allah dalam Alquran, yaitu: bangkai, darah, daging babi, dan daging yang disembelih bukan karena Allah. Berdasarkan kaidah ini, maka lebih mudah untuk menentukan sesuatu itu halal atau haram.

Sedangkan perkara syubhat selalu menimbulkan perbedaan pendapat di antara para ulama. Telah dihasilkan berbagai kajian dan telaah mendalam dengan dipaparkannya berbagai pendapat para ulama untuk menentukan status halal atau haramnya. Kompleksitas penentuan hukum halal dan haram dalam kasus-kasus yang tidak dijelaskan nash sejak awal sudah digambarkan para Imam Madzhab fikih terdahulu meskipun mereka berbeda dalam memberikan definisi. ${ }^{14}$

Syubhat berarti kesamaran (karena tidak jelas hukumnya antara halal dan haram). Oleh karena itu sesuatu yang syubhat adalah sesuatu yang diperselisihkan status halal-haramnya, seperti daging kuda, minuman nabidz,dan pakaian dari kulit binatang buas. Contoh lain adalah campuran antara yang halal dan yang haram, seperti campuran dalam harta benda dan uang.

Al-Ghazali menjelaskan dalam Ihya' Ulum al-Din bahwa jika di suatu kawasan harta haram bercampur dengan yang halal dan tidak dapat dihitung seperti harta benda yang ada pada masa kini, maka tidak diharamkan bertransaksi pada harta benda tersebut, malah menurutnya dibolehkan mengambil harta benda itu. Namun jika bisa dibedakan antara harta yang halal dan harta yang haram, maka harus bertransaksi pada harta yang halal saja dan haram hukumnya bertransaksi pada harta yang haram. ${ }^{15}$ Diantara sebab yang menimbulkan syubhat(kesamaran) hukum halal dan haram adalah pertentangan dua dalil yang kontradiktif, atau yang satu jelas dan yang lain tidak jelas.

Dalam hukum Islam terdapat beberapa prinsip dasar yang perlu difahami dalam hukum halal dan haram, prinsip dasar tersebut adalah:

Pertama, Yang dapat menentukan halal dan haram hanyalah Allah SWT sebagai Tuhan yang berhak menentukan semua itu. Tidak ada seorang pun yang dapat menentukan halal dan haram setelah Allah kecuali hanya Rasulullah SAW dengan panduan dan tuntunan wahyu yang berasal dari Allah SWT. ${ }^{16}$

14Thabrani, "Esensi Ta'abbud Dalam Konsumsi Pangan."

${ }^{15 J a l a l u d d i n ~ S u y u t h i, ~ A l-A s y b a h ~ W a ~ A l-N a d h a ' i r ~(B e i r u t: ~ D a r ~ a l-K i t a b ~ a l-A r a b i, ~ 1996) . ~ p . ~} 213$.

${ }^{16}$ Qardhawi, Al-Halal Wa Al-Haram Fi Al-Islam.

20 Profit : Jurnal Kajian Ekonomi dan Perbankan 
Kedua, Kaidah: "Asal segala sesuatu (yang diciptakan Allah SWT) adalah halal atau mubah (boleb)," oleh sebab itu janganmengharamkan sesuatu yang tidak diharamkan oleh Allah, dan janganmenghalalkan sesuatu kecuali yang telah ditentukan Allah dan rasul-Nya. Segala yang diharamkan secara jelas berdasarkan dalil Alquran dan Sunnah, maka ia adalah haram. Namun segala yang tidak disebutkan keharamannya, maka ia masih berada pada hukum asal, yaitu boleh. ${ }^{17}$ Kaidah ini tidak berlaku pada urusan ibadah, hukum asal ibadah adalah sesuai yang ditentukan oleh syariah, karena ibadah bersifat tanqifi dan rasa tunduk dan patuh.

Ketiga, Sesungguhnya Allah hanya menghalalkan sesuatu yang baik dan mengharamkan sesuatu yang buruk (kotor). Hak Allah adalah menghalalkan dan mengharamkan yang Dia inginkan, tetapi karena Maha Lembut dan Maha Penyayang Allah pada umat manusia, Allah hanya mengharamkan yang buruk (kotor) dan menghalalkan yang baik. Segala sesuatu yang baik dan memiliki manfaat nyata, maka hukumnya halal dan segala sesuatu yang buruk (kotor) dan berbahaya maka hukumnya haram. ${ }^{18}$

Keempat, Allah SWT tidak mengharamkan sesuatu karena ingin menyiksa atau menyempitkan hidup umat Muhammad. Hal ini berbeda dengan apa yang terjadi pada umat-umat sebelumnya seperti Bani Israil dan umat yang lain. Allah SWT mengharamkan beberapa barang yang baik pada Bani Israil, padahal sebelumnya barang-barang tersebut dihalalkan. Ketentuan itu ditetapkan Allah pada Bani Israil sebagai balasan atas kekufuran mereka sebagaimana yang dijelaskan dalam QS. Annisa' (4): 163.

Kelima, Ketika Allah mengharamkan sesuatu, maka sesuatu itu haram meskipun hanya sedikit,meskipun sesuatu itu hanya kecil. Hal ini karena, alasan diharamkannya tetap ada pada sesuatu itu meskipun hanya sedikit atau kecil.

Keenam, Apabila Islam telah mengharamkan sesuatu, maka wasilah dan cara apapun yang dapat membawa kepada perbuatan haram, hukumnya adalah haram. Oleh sebab itu, ketika Allah SWT mengharamkan zina, maka Allah juga mengharamkan semua yang menjadi penyebab terjadinya zina seperti berpakaian terbuka, berkhalwah (berdua-duaan), bercampur lelaki perempuan, berfoto telanjang, dan musikatau nyanyi-nyanyian yang mengundang syahwat. Dari prinsip ini para ahli fikih membuat suatu kaidah: "Apa saja yang membawa kepada perbuatan haram, maka itu adalah haram". ${ }^{19}$

\footnotetext{
${ }^{17}$ Suyuthi, Al-Asybah Wa Al-Nadha'ir. p. 133

${ }^{18}$ Qardhawi, Al-Halal Wa Al-Haram Fi Al-Islam.

${ }^{19}$ Suyuthi, Al-Asybah Wa Al-Nadha'ir.
}

21 Profit : Jurnal Kajian Ekonomi dan Perbankan 
Ketujuh, Halal dan haram adalah aturan yang sudah jelas.Diantara hikmah hukum halal dan haram adalah Allah telah membedakan antara halal dan haram sehingga umat Islam tahu perbedanya dengan jelas. Diantara barang halal dan haram ada barang yang syubhat yang tidak diketahui oleh banyak orang sehingga dijauhi oleh orang yang wara'. Wara' merupakan satu sikap berhati-hati karena takut berbuat haram. Dengan sifat ini seorang Muslim diharuskan untuk menjauhkan diri dari masalah yang masih syubhat, sehingga dengan demikian dia tidak akan terseret untuk berbuat yang haram. ${ }^{20}$

\section{Halal dalam Ekonomi Syariah}

Ajaran Islam berkaitan dengan halal dan haram meliputi seluruh kegiatan ekonomi manusia, terutama yang berkaitan dengan poduksi dan konsumsi, baik dalam hal kekayaan maupun makanan. Selain itu, halal dan haram juga berkaitan dengan perilaku dan aktifitas ekonomi atau muamalah, seperti jual beli, sewa menyewa, praktik riba dan yang lain.

Dalam bidang produksi, halal merupakan salah satu batasan produsen untuk mengeluarkan atau memproduksi barang dan jasa.Seorang Muslim harus menghindari praktek produksi yang mengandung unsur haram, riba, pasar gelap dan spekulasi. ${ }^{21}$ Alquran menjelaskan akan hal itu: "Hai orang-orang yang beriman sesungguhnya meminum khamr, berjudi, berbala dan mengundi nasib dengan panah adalab (perbuatan) keji termasuk perbuatan setan. Maka jaubilah perbuatan-perbuatan itu agar kamu mendapat keberuntungan." (QS. Almaidah (5): 90) Ayat ini memberi pengertian larangan memproduksi barang yang diharamkan seperti minuman keras (khamr), berhala, serta barang-barang haram yang lain.

Al-Ghazali membagi produksi dalam tiga tingkatan, yaitu: industry dasar, aktivitas pendukung, dan aktivitas komplementer. Industry dasar adalah industry yang menjaga kelangsungan hidup manusia, yakni agrikultur (produsen makanan), tekstil (produsen sandang), kontruksi (produsen papan), dan aktivitas Negara. Aktivitas pendukung adalah aktivitas yang bersifat tambahan bagi industry dasar, sedangkan aktivitas komplementer merupakan aktivitas yang berkaitan denga industry dasar seperti pengilingan padi. Pemenuhan ketiganya merupakan kewajiban social sekaligus juga tugas ilahiah. ${ }^{22}$

Yunus al-Mashri memberi batasan praktik produksi dengan beberapa batasan, yaitu: (1) memproduksi barang dan jasa yang halal lagi baik yang bermanfaat bagi manusia. Jadi, haram

${ }^{20}$ Qardhawi, Al-Halal Wa Al-Haram Fi Al-Islam.

${ }^{21}$ Heri Sudarsono, Konsep Ekonomi Islam, Suatu Pengantar (Yogyakarta: Ekonisia UII, 2002). p. 174.

${ }^{22} \mathrm{Q}-$ Anees, Filsafat Ekonomi Islam.p. 99.

22 Profit : Jurnal Kajian Ekonomi dan Perbankan 
hukumnya memproduksi barang yang kotor yang bisa membahayakan akal, jiwa, dan raga manusia. Barang dan jasa yang dihasilkan dari praktek produksi harus memberi manfaat pada umat manusia serta menambah mereka bahagia. (2) prioritas produksi adalah pada barang dan jasa yang menjadi kebutuhan primer (Dharuriyat) manusia. Jika barang kebutuhan primer sudah terpenuhi, maka memproduksi barang-barang kebutuhan skunder (Hajiyat) dan setelah itu barang-barang kebutuhan tersier (Tabsiniyat). ${ }^{23}$ Seorang produsen harus mengalokasikan faktor-faktor produksi untuk memproduksi barang dan jasa sesuai tingkat kebutuhan dan kemaslahatan manusia.

Sedangkan dalam bidang konsumsi, halal merupakan prinsip penting yang harus ditaati oleh konsumen selain prinsip yang lain. Islam telah menentukan tiga prinsip dasar dalam konsumsi, yaitu: prinsip konsumsi barang halal, konsumsi barang suci dan bersih serta prinsip tidak berlebihan.

Seorang Muslim diperintahkan untuk makan makanan yang halal (sah menurut hukum dan diizinkan) dan tidak menggambil yang haram (tidak sah menurut hukum dan terlarang). Alquran menyatakan: "... makanlah makanan yang halal lagi baik dari apa yang Allah telah rezekikan padamu, dan bertakwalah kepada Allah yang kamu beriman kepada-Nya.” (QS. Almaidah (5): 88). Di ayat lain (QS. Almaidah (5): 3), Alquran juga menyebutkan ada 4 makanan yang diharamkan. Prinsip halal dan haram juga berlaku bagi hal lain selain makanan. Umat Islam diharuskan membelanjakan pendapatannya hanya pada barang yang halal saja dan dilarang membelanjakan pada barang haram seperti minuman keras, narkoba, judi, pelacuran, kemewahan, dan sebagainya. ${ }^{24}$

Prinsip konsumsi Islam yang masih ada kaitannya dengan prinsip halal adalah, prinsip kebersihan dan menyehatkan. Alquran telah mengingatkan manusia untuk makan makanan yang baik yang telah Allah anugerahkan kepada manusia. Makanan yang baik adalah makanan yang bersih dan menyehatkan dan tidak menimbulkan bahaya pada tubuh, akal, dan juga pikiran. Banyak ayat Alquran yang telah menjelaskan hal itu, diantaranya adalah firman Allah SWT yang artinya: "Maka makanlah yang halal lagi baik (tayyib) dari rezeki yang telah diberikan Allah kepadamu, dan syukurilah nikmat Allah, jika kamu hanya kepada-Nya saja menyembah.” (QS. Annahl (16): 114)

Ayat Alquran tersebut menyandingkan kata "halal" dengan kata "tayyib” sebagai syarat barang yang boleh dikonsumsi oleh umat Islam. Kata "tayyib" memiliki arti menyenangkan, manis, diizinkan, menyehatkan, suci, dan kondusif untuk kesehatan. Dengan dua syarat barang yang boleh dikonsumsi

${ }^{23}$ Rafiq Yunus Mashri, Ushul Al-Iqtishad Al-Islami (Beirut: al-Dar al-Samiyah, 1993). p. 104.

${ }^{24}$ Muhammad Sharif Chaudhry, Fundamental of Islamic Economic System (Edisi Terjemah) (Jakarta: Kencana, 2012). p. 138.

23 Profit : Jurnal Kajian Ekonomi dan Perbankan 
tersebut,maka itu berarti bahwa Allah SW'T melarang mengkonsumsi barang-barang yang tidak suci, tidak menyenangkan, buruk dan tidak sedap dipandang. ${ }^{25}$

Konsep halal dan tayyib (baik) telah menggariskan panduan bagi hal-hal yang dibolehkan untuk dikonsumsi. Dalam memilih makanan dan minuman, kehalalan adalah hal yang mesti diutamakan. Dalam Alquran terdapat banyak ayat yang menyebutkan perintah Allah SWT supaya mengkonsumsi makanan yang halal dan larangan memakan makanan yang haram. Hal ini karena, Allah SWT hanya menerima perkara yang baik saja sebagaimana dikatakan Nabi SAW. ${ }^{26}$ Orang-orang yang beriman diingatkan untuk hanya makan makanan yang baik dan menjauhkan diri dari makanan yang buruk. Telah diriwayatkan dari Jabir bahwa Rasulullah SAW bersabda: "Jika kamu hendak tidur, matikanlah lampu, tutuplah pintu, dan tutuplah tempat makanan dan minuman." (HR. al-Bukhari) Hadis lain menyebutkan: "Barakah makanan terletak pada mencuci tangan sebelum dan sesudah memakannya." (HR. alTirmidzi)

Hadis tersebut di atas secara jelas menunjukkan bahwa hal yang baik (tayyib) begitu ditekankan dalam Islam dan semestinya dianggap dan dipandang sebagai sesuatu yang serius dan dititikberatkan dalam kehidupan sehari-hari, khususnya dalam pemilihan makanan dan minuman yang akan dikonsumsi. Kata tayyib (baik) sendiri memiliki banyak definisi sebagaimana yang dijelaskan oleh para ulama. Al-Shabuni mendefinisikan bahwa semua yang dihalalkan oleh Allah SWT adalah baik, dan semua yang diharamkan Allah SWT adalah tidak baik. ${ }^{27}$

Sedangkan al-Qurthubi dalam tafsirnya tidak menjelaskan arti perkataan tayyiban tetapi hanya menguraikan arti kataal-akl (makanan) yang baik yang memberi manfaat dari berbagai aspeknya. Meski demikian,al-aklyang diberikan arti sebagaimana dimaksud mempunyai persamaan dengan arti kata thayyib. Al-Ghazali menyatakan bahwa setiap yang halal itu baik, akan tetapi bentuk kebaikannya mempunyai perbedaan antara satu dengan yang lain.Wahbah al-Zuhaily mengatakan, kata tayyiban yang berkaitan dengan makanan memiliki arti tidak mempunyai unsur syubhat, tidak berdosa (jika mengambilnya) dan tidak memiliki kaitan dengan hak orang lain. Pendapat ini tidak saja menekankan pada aspek zat makanan, tapi juga menekankan proses mendapatkannya serta sumber didapatkannya. ${ }^{28}$

\footnotetext{
${ }^{25}$ Ibid.

${ }^{26}$ Kasmawati, Makna Halal Dan Tayyib Perspektif Al-Quran (Makasar, 2014).

27Shabuni, Shafwah Al-Tafasir.

${ }^{28}$ Wahbah Zuhaily, Tafsir Al-Wajiz Wa Mu'jam Ma'ani Al-Quran Al-Aziz (Damaskus: Dar al-Fikr, 1995). p. 281.
}

24 Profit : Jurnal Kajian Ekonomi dan Perbankan 
Ada beberapa rumusan untuk konsep halal dan baik (tayyib) dalam konsumsi yang dapat dijadikan acuan kita untuk beribadah pada Allah, yaitu:

Pertama, Kebersihan dan kesucian,makanan dan minuman yang halal telah jelas dimaklumi, tapi ada beberapa hal yang kurang disadari dan diperhatikan, termasuk proses pembuatan, kebersihan, kesucian, alat masak, dan tempatnya. Dalam hal ini perlu diperhatikan: (1) tidak termasuk hewan yang dilarang atau tidak disembelih sesuai syariah; (2) tidak mengandung najis, termasuk (minyak) babi, bangkai, atau narkoba; (3) proses, alat, dan bumbu bebas dari najis; (4) tidak bercampur dengan yang haram, baik dalam penyediaan, proses, atau penyimpanannya. ${ }^{29}$

Kedua, Sumber,sumber konsumsi dimaksudkan sebagai segala sesuatu yang dikaruniakan oleh Allah untuk keperluan rohani dan jasmani manusia. Bisa berupa pendapatan, penghasilan, pencarian (kebutuhan hidup).Sumber rezeki mempunyai kaitan langsung dengan makanan atau minuman yang dikonsumsi. Hal ini karena,jika sumber rezeki yang diperoleh haram atau syubhat, maka makanan itu dianggap haram. Padahal Rasulullah SAW telah nengingatkan: "Setiap daging yang tumbub dari sesuatu yang haram, maka neraka lebih berbak baginya." (HR. al-Thabrani)

Ketiga, Tidak merusak fisik dan mental,makanan dan minuman yang halal pada hakikatnya adalah baik, namun seperti yang telah dijelaskan oleh al-Syathibi bahwa parameter baik merupakan hal yang nisbi (subyektif) artinya mengandung kesesuaian yang berbeda antara satu orang dengan orang yang lain. ${ }^{30}$ Maksudnya, harusbijak memilih makanan yang betul-betul sesuai dengan keadaan fisik dan mental kita. Bagi yang sakit gula (diabet), kandungan gula yang berlebihan dalam makanan atau minumanakan berbahaya bagi kesehatan mereka sehingga hukumnya haram. Walaupun pada asalnya makanan tersebut halal dan baik, tetapi orang yang mengindap penyakit gula harus menghindari gula yang berlebihan karena dapat menggannggu kesehatan. Allah SWT berfirman yang arinya: "Dan janganlah kamu menjatubkan dirimu sendiri ke dalam kebinasaan." (QS. Albaqarah (2): 195)

Keempat, Tidak mengandung syubhat,dasar rumusan ini adalah hadis: "Sesungghubnya halal itu jelas, dan haram itu juga jelas. Diantara keduanya ada hal-hal yang tidak jelas (syubhat) yang tidak diketabui oleh banyak orang. Barang siapa takut atau menjaubui hal-hal yang syubhat, maka ia telah mencari kebersihan agama dan harga dirinya. Dan barang siapa terjerumus pada hal-hal yang tidak jelas (syubhat), maka ia telah terjerumus ke dalam perkara haram." (HR. al-Bukhari dan Muslim).Hadis tersebut menjelaskan tentang tiga hal,

${ }^{29}$ Qardhawi, Al-Halal Wa Al-Haram Fi Al-Islam.

${ }^{30}$ Mashri, Ushul Al-Iqtishad Al-Islami.p. 157.

25 Profit: Jurnal Kajian Ekonomi dan Perbankan 
dan yang sulit dihindari adalah yang sebagian besar orang tidak mengetahui atau menyadari, yaitu tentang syubhat.

Syubhatbisa terjadi dalam kondisi adanya keraguan dan pencampuran. Keraguan dalam hal sebab mengapa sesuatu dihalalkan atau diharamkan. Sedangkan percampuran bisa saja terjadi jika sesuatu yang haram bercampur baur dengan sesuatu yang halal, sehingga sukar untuk dibedakan diantara keduanya. Dan jika terjadi percampuran antara yang halal dan haram, maka dimenangkan yang haram sebagaimana yang dijelasan kaidah fikih. ${ }^{31}$

Cara terbaik untuk mengelakkan diri dari makanan yang syubhat adalah dengan sikap wara'. Sikap wara'pernah diajarkan oleh Rasulullah SAW ketika melihat Hasan bin Ali mengambil kurma dari harta sedekah, padahal waktu itu Hasan bin Ali masih kecil. Maka, di saat Rasulullah melihat kejadian itu Rasul berkata: “bakh, bakh” (buang! buang!) dan kurma itu pun dikeluarkan dari mulut Hasan. Dan banyak lagi peristiwa lainnya yang dialami oleh para sahabat Nabi.Seperti yang pernah terjadi pada sahabat Umar ibn al-Khaththab, Umar pernah minum susu dari seekor unta sedekah, lalu ia pun ragu dan merasa keliru.Kemudian Umar memasukkan jari-jarinya ke dalam mulut dan berusaha memuntahkansusu itu dari perutnya hingga bersih. ${ }^{32}$

Manakala konsep halal dalam aktifitas ekonomi tercermin pada praktik pertukaran. Praktik pertukaran meliputi jual beli, sewa, partnership (musyarakah), ju'alah dan jenis pertukaran yang lain. Pertukaran sangat penting untuk keberlangsungan hidup manusia karena setiap orang tidak dapat menghasilkan semua keperluan hidupnya. Setiap orang hanya dapat menghasilkan sebagian keperluan hidupnya dan keperluan hidup yang lain dipenuhi dari orang lain dengan cara pertukaran. Al-Izz bin Abdusalam berkata: "Seandainya Islam tidak menghalalkan praktik pertukaran, nescaya manusia akan rusak." 33

Konsep pertukaran pada awalnya berupa pertukaran barang dengan barang atau yang kita kenal dengan system barter. Namun dengan berkembangnya waktu system barter berubah dengan system jual beli, yaitu menukarkan uang dengan barang yang diperlukan. ${ }^{34}$ Allah SWT dengan tegas menghalalkan jual beli dan mengharamkan riba dalam firman-Nya: “... padahal Allah telah menghalalkan jual beli dan mengharamkan riba." (QS. Albaqarah (2): 275).

\footnotetext{
${ }^{31}$ Suyuthi, Al-Asybah Wa Al-Nadha'ir.

${ }^{32}$ Kasmawati, Makna Halal Dan Tayyib Perspektif Al-Quran.

${ }^{33}$ al-Izz bin Abdussalam, Qawa'id Al-Ahkam Fi Mashalih Al-Anam (Beirut: Dar al-Fikr, 2004). Vol. 1, p. 235.

${ }^{34}$ Afzalur Rahman, Economic Doctrines of Islam (Lahore: Islamic Publication.Ltd., 1985). vol. 2, p. 49. 
Meskipun hukum asal jual beli adalah halal, namun ada beberapa jenis jual beli yang diharamkan karena mengandung unsur-unsur yang menyebabkan jual beli diharamkan. Diantara unsur-unsur yang menyebabkan jual beli dilarang adalah riba, penipuan, penindasan, kedzaliman dan mengarah kepada sesuatu yang dilarang Islam. Misalnya jual beli minuman keras, babi, narkoba, berhala, patung dan sebagainya yang sudah jelas oleh Islam diharamkan, baik memakannya, mengerjakannya atau memanfaatkannya. ${ }^{35}$

Semua harta yang diperoleh dengan jalan haram adalah suatu dosa. Dan setiap daging yang tumbuh dari dosa (haram), maka nerakalah tempatnya. Orang yang memperjualbelikan barangbarang haram tidak dapat diselamatkan karena kebenaran dan kejujurannya. Sebab barang yang diperjualbelikan itu sendiri sudah mungkar yang ditentang dan tidak dibenarkan oleh Islam.

Diantara contoh jual beli yang diharamkan adalah:Munabazah (jual beli dengan cara mencampakkan barang yang dijual ke pembeli), Mulamasah (jual beli dengan cara pembeli menyentuh barang yang akan dibeli), Muzabanah (jual beli buah-buahan segar dengan yang buah-buahan kering), Muhaqalah (jual beli biji yang belum disemai dengan biji kering), Najsh (jual beli dengan menaikkan harga barang tanpa ada keinginan membeli), dan masih banyak lagi contoh jual beli yang dilarang dalam Islam. ${ }^{36}$

\section{Kesimpulan}

Islam menjelaskan bahwa aturan halal (mubah) dan haram tidak berdasarkan pada keperluan individu ataupun masyarakat. Namun, aturan halal dan haram merupakan urusan Tuhan yang tidak mungkin untuk diganti. Manusia tidak berhak untuk menganti aturan halal dan haram sesuai dengan hawa nafsu mereka. Halal telah menjadi salah satu kerangka nilai ilmu pengetahuan Islam yang berfungsi sebagai penuntun atau pembimbing. ${ }^{37}$ Oleh sebab itu dari pemaparan sebelumnya dapat diambil kesimpulan tentang filsafat halal.

Ontologimerupakan bagian dari ilmu pengetahuan lebih berkonsentrasi untuk mengkaji tentang hakikat sesuatu. Kaitannya dengan aturan halal, ontologi berusaha memaparkan asal-muasal (hakikat) dari aturan halal itu sendiri.Halal sebagai bagian dari ilmu tentang ekonomi syariah berangkat dari teks nashAlquran dan hadis yang memiliki nilai kebenaranmutlak. Dalam Islam, sandaran paling diakui terkait dengan disiplin ilmu adalah wahyu Tuhan. Banyak ayat Alquran yang

${ }^{35}$ Qardhawi, Al-Halal Wa Al-Haram Fi Al-Islam.

${ }^{36}$ Rahman, Economic Doctrines of Islam.

${ }^{37}$ Q-Anees, Filsafat Ekonomi Islam.p. 276.

27 Profit : Jurnal Kajian Ekonomi dan Perbankan 
menjelaskan tentang aturan halal sebagai bagian dari ekonomi syariah diikuti dengan penjelasan dari hadis Nabi SAW sebagai dasar kedua dalam ajaran Islam.

Dari sisi epistemology, aturan halal mengacu kepada usaha untuk memahami Islam secara benar melalui proses kajian yang benar. Tidak dapat dipungkiri bahwa aturan halal adalah bagian dari hukum Islam yang terkait langsung dengan ekonomi syariah. Epistemologi halal berkaitan dengan usaha atau "ijtihad” untuk menerapkan aturan halal dalam transaksi-transaksi ekonomi syariah. Untuk itu, perlu menjaga nilai-nilai Islam agar tidak keluar dari kaidah yang benarkarena pada akhirnya transaksi dalam ekonomi syariah akan memasuki wilayah praktis.

Manakala dari sisi aksiology, aturanhalal tentu sangat berperan dalam memberikan panduan yang benar bagi umat manusia dalam menjalani hidup. Dengan berpandukan aturan halal, umat Islam dapat menjalankan kehidupan ekonominya dengan baik dan terarah, baik dari segi produksi, konsumsi, maupun aktifitas pertukaran. Dimana arah dan tujuan hidup tersebut pada akhirnya hanya menuju Allah SWT. Era revolusi industry 4.0 sekarang ini menuntut kita untuk mengembangkan diri, khususnya dalam menguasai aturan halal dan haram yang telah digariskan Allah dan Rasulullah disesuaikan dengan tantangan zaman yang semakin maju ini. Wallabu a'lam

\section{DAFTAR PUSTAKA}

Abdussalam, al-Izz bin. Qawa'id Al-Ahkam Fi Mashalih Al-Anam. Beirut: Dar al-Fikr, 2004.

Chaudhry, Muhammad Sharif. Fundamental of Islamic Economic System (Edisi Terjemab). Jakarta: Kencana, 2012.

Hamshi, Muhammad Hasan. Quran Karim, Tafsir Wa Bayan. Beirut: Dar al-Rasyid, n.d.

Kasmawati. Makna Halal Dan Tayyib Perspektif Al-Quran. Makasar, 2014.

Mashri, Rafiq Yunus. Ushul Al-Iqtishad Al-Islami. Beirut: al-Dar al-Samiyah, 1993.

Munawwir, Ahmad Warson. Al-Munawwir (Kamus Arab-Indonesia). Surabaya: Pustaka Progresif, 1997.

Q-Anees, M. Antor Athoillah and Bambang. Filsafat Ekonomi Islam. Bekasi: Penerbir Sahifa, 2013.

Qardhawi, Yusuf. Al-Halal Wa Al-Haram Fi Al-Islam. Kairo: Maktabah Wahbah, 2000.

Rahman, Afzalur. Economic Dctrines of Islam. Lahore: Islamic Publication.Ltd., 1985.

Shabuni, Muhammad Ali. Shafwah Al-Tafasir. Kairo: Dar al-Salam, 1996. 
Shihab, M. Quraish. Ensiklopedi Al-Quran: Kajian Kosakata. Jakarta: Lentera Hati, 2000.

—. Tafsir Al-Misbah, Kesan, Pesan Dan Keserasian Al-Quran. Jakarta: Lentera Hati, 2001.

Sudarsono, Heri. Konsep Ekonomi Islam, Suatu Pengantar. Yogyakarta: Ekonisia UII, 2002.

Suyuthi, Jalaluddin. Al-Asybah Wa Al-Nadha’ir. Beirut: Dar al-Kitab al-Arabi, 1996.

Thabrani, Abdul Mukti. "Esensi Ta’abbud Dalam Konsumsi Pangan.” al-Ibkam 8, no. 1 (2013): 5568.

Zuhaily, Wahbah. Tafsir Al-Wajiz,Wa Mu’jam Ma'ani Al-Quran Al-Aziæ. Damaskus: Dar al-Fikr, 1995. . Ushul Fiqh Al-Islami. Beirut: Dar al-Fikr, 1996. 